\title{
Hemşirelik Öğrencilerinin Empatik Eğilimleri ve Bireyselleştirilmiş Bakım Algıları
}

\author{
Aslı ER KORUCU ${ }^{1}$, (D) Yasemin ÇEKİÇ², (iD Fatma USLU ŞAHAN ${ }^{3}$
}

'Öğr. Gör.Dr., Ankara Üniversitesi, Hemşirelik Fakültesi, Ebelik Bölümü, Ankara, Türkiye.

${ }^{2}$ Arş. Gör. Dr., Ankara Üniversitesi, Hemşirelik Fakültesi, Hemşirelik Bölümü, Ankara, Türkiye.

${ }^{3}$ Dr. Öğr. Üyesi, Hacettepe Üniversitesi, Hemşirelik Fakültesi, Doğum ve Kadın Hastalıkları Hemşireliği Anabilim Dalı, Ankara, Türkiye.

$\ddot{\mathbf{O} z}$

Giriş: Hemşirelerin empatik eğilimleri bireyselleştirilmiş bakım algılarını etkilemektedir. Amaç: Araştırma, hemşirelik öğrencilerinin empatik eğilim düzeyleri ile bireyselleştirilmiş bakım algıları arasındaki ilişkinin belirlenmesi amacıyla gerçekleştirilmiştir. Yöntem: Araştırma tanımlayıcı ve ilişki arayıcı tipte yapılmıştır. Araştırmanın örneklemini bir devlet üniversitesinin 2020-2021 eğitim-öğretim yılı güz döneminde hemşirelik bölümüne kayıtlı bulunan 227 ögrenci oluşturmuştur. Araştırma verileri Tanıtıcı Özellikler Formu, Empatik Eğilim Ölçeği ve Bireyselleştirilmiş Bakım Skalası-Hemşire ile toplanmıştır. Verilerin değerlendirilmesinde tanımlayıcı istatistikler, Student's t testi, Tek Yönlü Varyans Analizi, Tukey testi ve Pearson korelasyon analizi kullanılmıştır. Bulgular: Öğrencilerin Empatik Eğilim Ölçeği toplam puan ortalamasının $68.14 \pm 8.52$, Bireyselleştirilmiş Bakım Skalası-Hemşire toplam puan ortalamasının $4.13 \pm 0.56$ olduğu saptanmıştır. Bireyselleştirilmiş Bakım Skalası-Hemşire alt boyut ortalamalarının sırasıyla karar verme kontrolü (4.18 \pm 0.63$)$, klinik durum (4.17 \pm 0.59$)$ ve kişisel yaşam durumu (3.98 \pm 0.71$)$ olduğu belirlenmiştir. Empatik Eğilim Ölçeği ile Bireyselleştirilmiş Bakım Skalası-Hemşire alt boyutları arasındaki ilişki incelendiğinde ise Empatik Eğilim Ölçeği ile klinik durum alt boyutu arasında pozitif yönlü orta düzeyde $(\mathrm{r}=.413, \mathrm{p}=.001)$, kişisel yaşam durumu alt boyutu $(\mathrm{r}=.283, \mathrm{p}=.001)$ ve karar verme alt boyutu $(\mathrm{r}=.329, \mathrm{p}=.001)$ arasında pozitif yönde zayıf bir ilişki saptanmıştır. Sonuç: Araştırmada hemşirelik öğrencilerin empatik eğilimlerinin orta düzeyde; bireyselleştirilmiş bakım algılarının iyi düzeyde olduğu; öğrencilerin empatik eğilimleri arttıkça bireyselleştirilmiş bakım algılarınında arttığı belirlenmiştir.

Anahtar Sözcükler: Hemşirelik Öğrencisi, Empatik Eğilim, Bireyselleştirilmiş Bakım.

\begin{abstract}
Nursing Students' Empathic Tendencies and Individualized Care Perceptions

Background: Nurses' empathic tendencies influence their perceptions of individualized care. Objective: The study aims to determine the relationship between nursing students empathic tendencies and individualized care perceptions. Methods: This study employed a descriptive and correlational design the sample of the study consisted of 227 students enrolled in the nursing department of a state university in the fall semester of the 2020-2021 academic year. Data were collected with the Introductory Specifications Form, Empathic Tendencies Scale, Individualized Care Scale-A-Nurse Version. For the analysis, descriptive statistics, Student's t test, One-way analysis of variance Tukey and Pearson's correlation were used. Results: It was determined that the students' total mean score on the Empathic Tendency Scale was $68.14 \pm$ 8.52, and the average total score of the Individualized Care Scale-Nurse was $4.13 \pm 0.56$. Individualized Care Scale-Nurse subscale means were determined to be decision-making control $(4.18 \pm 0.63)$, clinical status $(4.17 \pm 0.59)$ and personal life status $(3.98 \pm 0.71)$, respectively. A weak positive correlation was found between the Empathic Tendency Scale and the Individualized Care Scale-Nurse $(r=.396, p=.001)$. When the relationship between the Empathic Tendency Scale and the Individualized Care Scale-Nurse sub-dimensions was examined, there was a moderate positive $(\mathrm{r}=.413, \mathrm{p}=.001)$, personal life situation sub-dimension $(\mathrm{r}=.283, \mathrm{p}=.001)$ A weak positive correlation was found between the decision sub-dimension $(r=.329, \mathrm{p}=.001)$. Conlusion: In the study, empathic tendencies of nursing students are at medium level; good individualized care perceptions; It was determined that as the empathic tendencies of students increased, their individualized care perceptions increased.

Key Words: Nursing Student, Empathic Tendency, Individualized Care.
\end{abstract}

\footnotetext{
Geliş Tarihi / Received: 05.03.2021 Kabul Tarihi / Accepted: 03.09.2021

Correspondence Author: Öğr. Gör.Dr., Ankara Üniversitesi, Hemşirelik Fakültesi, Ebelik Bölümü, Hacettepe Mahallesi Plevne Caddesi No:7 PK: 06230 Altındağ / ANKARA. Telefon: +90 (312) 3195018 E-posta: akorucu@ankara.edu.tr

Cite This Article: Er Korucu A, Çekiç Y, Uslu Şahan F. Hemşirelik Öğrencilerinin Empatik Eğilimleri ve Bireyselleştirilmiş Bakım Algıları. Dokuz Eylül Üniversitesi Hemşirelik Fakültesi Elektronik Dergisi. 2021; 14(4): 370- 378
} 
$\mathbf{H}$ emşireler temel sorumlulukları olan bakım işlevlerini, sağlıklı/hasta bireylerle sürdürdükleri kişiler arası ilişkiler yolu ile yerine getirmektedirler. Kişiler arası etkileşim süreci hemşireliğin önemli bir parçasıdır $(1,2)$. Hemşire ve sağlıklı/hasta bireyler arasında sürdürülen ilişkide, kullanılan becerilerle beraber terapötik ilişkinin kurulması da oldukça önemlidir $(2,3)$. Empatinin, hemşire-hasta arasındaki terapötik ilişkinin kurulmasında ve hemşirelik bakımında oldukça önemli bir yeri olduğu bilinmektedir (4).

Hemşirelikte empati, kanıta dayalı yapıcı yaklaşımlarla sağlıklı iletişim kurarak hastanın duygu ve düşüncelerini tam olarak anlama ve paylaşma yeteneği olarak tanımlanmaktadır (2). Empatinin bilişsel, duygusal ve davranışsal olmak üzere üç boyutu bulunmaktadır. Bireyin başkalarıyla olan iletişim kurma potansiyelini ve arzusunu gösteren ve empatinin duygusal boyutunu kapsayan ise empatik eğilimdir $(5,6)$. Empatik eğilim yüksek hasta memnuniyeti $(7,8)$ ve tedaviye uyum $(7,9)$ gibi olumlu hasta sonuçlarının sağlanması ve bakım kalitesinin arttırılması açısından çok değerlidir. Bu nedenle empatinin, kaliteli hemşirelik bakımı ve hasta merkezli bir terapötik ilişkinin gelişmesi açısından vazgeçilmez bir unsur olduğu unutulmamalıdır $(7,9)$.

Hasta bakımında standardize edilmiş protokollerin kullanılması, hastalar arasındaki bireysel farklılıklar olduğu gerçeğinden bakım vereni uzaklaştırmaktadır (10). Bireyselleștirilmiş bakım ise standardize edilmiş prosedürler ve etkinliklere yerine her hastaya özel ve uyumlu hale dönüştürülülen bir bakımdır. Özellikle kaliteli bir hemşirelik bakımının sağlanmasında bireyin kişisel özelliklerine, ihtiyaçlarına, inanç ve değerlerine dikkat edilmesi ve verilen bakıma hastanın dahil edilmesi, bakımın bireyselleştirilebilmesi açısından önem taşımaktadır (3, 11). Ayrıca bireyselleştirilmiş bakım, hemşire ve sağlıklı/hasta birey arasındaki terapötik bir ilişki sonucu oluşan müdahalelerin göstergesi olarak da tanımlanmaktadır (12). Bireyselleştirilmiş bakımda hemşireler bireyin fizyolojik ihtiyaçlarını karşılamakla kalmayıp, empatik bir yaklaşım ile duygusal gereksinimlerinin karşılanmasına da katkı sağlamaktadırlar $(11,12)$. Literatürde de bireyselleştirilmiş bakım sunulan hastaların tedaviye uyumlarının daha iyi $(3,10,13)$ ve memnuniyet düzeylerinin yüksek olduğu vurgulanmaktadır $(3,11,14)$.

Hemşirelik eğitimi ile öğrencilerin, yaşadıkları dünyayı ve toplumu tanımaları ve hemşire olmak için gerekli yeterliliklerin kazandırılması amaçlanmaktadır $(3,11)$. Sağlıklı/hasta bireylerin ve ailelerinin bireyselleştirilmiş bakım gereksinimlerinin karşılanmasında öğrencilerin eğitimleri süresince temel mesleki değerleri kazanmaları ve empatik eğilim düzeylerinin geliştirilmesi oldukça önemlidir (3). Bu noktadan hareketle, hemşirelik öğrencilerinde empatik eğilimin belirlenmesi ve geliştirilmesi, öğrencilerin bireyselleştirilmiş bakımı özümseyebilmeleri ve uygulayabilmeleri için önemlidir. Literatürde hemşirelik öğrencilerinin empatik eğilimlerini ve bireyselleştirilmiş bakım algılarını birlikte değerlendiren bir araştırmaya rastlanmamıştır. Literatüre ve hemşirelik eğitimine katkı ve yenilik sağlayacağı düşünülerek gerçekleștirilen araştırmada, hemşirelik öğrencilerinin empatik eğilim düzeyleri ile bireyselleștirilmiş bakım algıları arasındaki ilişkinin belirlenmesi amaçlanmışırır.

\section{Araştırma Sorulart}

- Öğrencilerin bireyselleştirilmiş bakım algıları nasıldır?

- Öğrencilerin empatik eğilim düzeyleri nasıldır?

- Öğrencilerin tanıtıcı özellikleri ile bireyselleştirilmiş bakım algıları arasında anlamlı bir ilişki var mıdır?

- Öğrencilerin tanıtıcı özellikleri ile empatik eğilim düzeyleri arasında anlamlı bir ilişki var mıdır?

- Öğrencilerin empatik eğilim düzeyi ile bireyselleștirilmiş bakım algıları arasında anlamlı bir ilişsi var mıdır?

Yöntem

\section{Araştırmanın Tipi}

$\mathrm{Bu}$ araştırma tanımlayıcı ve ilişki arayıcı tiptedir.

\section{Araştırmanın Yapıldı̆̆ Yer}

Araştırma bir üniversitesinin hemşirelik fakültesinde 2020-2021 eğitim-öğretim yılı güz döneminde gerçekleştirilmiştir. Araştırmanın Evreni/Örneklemi

Araştırma evrenini, klinik uygulama deneyimi olan ikinci, üçüncü ve dördüncü sınıf hemşirelik öğrencileri $(N=568)$ oluşturmuştur. Birinci sınıf öğrencileri (148), klinik uygulama deneyimlerinin olmaması nedeni ile araştırmaya dahil edilmemiştir. Araştırmanın örneklemini onam alınan 227 hemşirelik öğrencisi oluşturmuştur. Araştırmaya katılım oranı $\% 54$ 'tür.

\section{Veri Toplama Araçlart-Geçerlik ve Güvenirlik Bilgileri}

Araştırmada veriler Tanıtıcı Özellikler Formu, Empatik Eğilim Ölçeği ve Bireyselleştirilmiş Bakım Skalası-Hemşire formları kullanılarak toplanmıştır.

Tanitıcı Özellikler Formu

Bu form, konu ilgili literatür $(5,14-16)$ taranarak araştırmacılar tarafından oluşturulmuştur. Formda, öğrencilerin tanıtıcı özellikleri (yaşı, cinsiyeti, sınıfı vb.) ile iletişim becerileri ve empatik becerilerinin geliştirilmesine yönelik eğitime katılma durumlarını belirlemeye yönelik dokuz soru bulunmaktadır.

Bireyselleştirilmiş Bakım Skalast-Hemşire (BBS-A-Hemşire)

Skala, Suhonen ve arkadaşları (2005) tarafindan sağlık hizmetlerinin sunumunda hemşirelerin bireyselleștirilmiş bakım hakkındaki görüşlerini değerlendirmek amacıyla geliştirilmiş (17); Acaroğlu ve arkadaşları (2011) tarafindan Türkçe geçerlilik ve güvenirliliği yapılmışıı (18). Skalanın iki bölümü bulunmaktadır. Hemşirelerin "bakım uygulamalarında hastaların bireyselliğini destekleme" (BBS-A Hemşire) algıları birinci bölümü oluşturmakta; "hastanın bakımını bireyselleştirme" (BBS-B Hemşire) algıları ikinci bölümü oluşturmaktadır. Bu araştırmada Bireyselleştirilmiş Bakım Skalasının, hemşirelerin bireyselleştirilmiş bakım algısını değerlendiren kısmı olan BBS-A bölümü kullanılmıştır. Ölçek 17 maddeden ve "klinik durum", "kişisel yaşam durumu" ve "karar verme kontrolü" olmak üzere üç alt boyuttan 
oluşmaktadır. Klinik durum alt boyutu; hemşirenin, bakım verdiği bireyin hastalığa yanıtlarını, duygularını ve hastalığının kendisi için anlamını dikkate alıp almadığını içeren yedi sorudan, kişisel yaşam durumu alt boyutu; hemşirenin, bakım verdiği bireyin inanç ve değerlerini yansıtan alışkanlıklarını, aktivitelerini, tercihlerini, aile bağlarının yanı sıra işi ve hastane deneyimi gibi özel bilgilerini dikkate alıp almadı̆̆ını içeren dört sorudan, karar verme kontrolü alt boyutu; hemşirenin, bakım verdiği bireyin kendi bakımında söz sahibi olmasına ve bakımı ile ilgili kararlara katılımına olanak sağlayıp sağlamadığını değerlendiren altı sorudan oluşmaktadır $(18,19)$. Likert tipte 1 ile 5 arasında puanlama yapılmaktadır. Toplam puan ve alt boyuta ilişkin puan ortalamaları; içerdikleri maddelerden alınan puanların toplanarak madde sayısına bölünmesi ile hesaplanır (19). Skaladan alınan puanın yüksek olması hemşirelerin bireyselleştirilmiş bakım algılarının yüksek olduğunu göstermektedir (17, 20). Orjinal skalanın toplam Cronbach alfa katsayısı .88 , türkçe geçerlilik ve güvenirliliği yapılan çalışmada .91 'dir. Bu araştırma için skalanın Cronbach alfa katsayısı .93 olarak hesaplanmıştır.

Empatik Ĕ̈ilim Ölçĕgi (EEÖ)

Dökmen (1988) tarafindan kişilerin günlük yaşamdaki empati kurma potansiyelini belirleyebilmek amacıyla geliştirilmiştir (21). 20 maddeden oluşan ve 1 ile 5 arasında puanlama yapılabilen likert tipte bir ölçektir. Ölçeğin 3,6 , $7,8,11,12,13,15$ numaralı maddeleri ters kodlanmaktadır. Ölçekten alınan toplam puan; içerdiği maddelerden alınan puanların toplanması ile hesaplanır. Toplam puanın artması empatik eğilimin yüksek olduğunu göstermektedir. Orjinal ölçeğin toplam Cronbach alfa katsayısı .82'dir. $\mathrm{Bu}$ araştırma için ölçeğin Cronbach alfa katsayısı .78 olarak hesaplanmiştır.

Veri toplama araçları "Google Formlar" sitesinde hazırlanarak çevrimiçi yanıtlanabilir özellikte düzenlenmiştir. Anket formu, öğrencilerin mail adreslerine 15 Ekim-15 Kasım 2020 tarihleri arasında e-posta yolu ile gönderilmiştir. Geri dönüş alınamayan öğrencilere 15-20 Kasım 2020 tarihlerinde tekrar e-posta atılmıştır.

Araştırmanın Değişkenleri

Araştırmanın bağımlı değişkenleri; empatik eğilim ve bireyselleştirilmiş bakım puanlarıdır. Bağımsız değişkenler ise; yaş, cinsiyet, sınıf, algılanan ekonomik durum, kişilik yapısı, aile tipi, hemşirelik mesleğini sevme durumu, iletişim ve empati becerilerinin geliştirilmesine yönelik eğitim alma durumu gibi öğrencilerin tanıtıcı özelliklerinden oluşmaktadır.

\section{Verilerin Değerlendirilmesi}

Araştırma verilerinin analizinde program olarak IBM SPSS Statistics 24 (SPSS Inc. Chicago, Illinois, USA) kullanılmıştır. Araştırmadan elde edilen bulgular tanımlayıcı istatistikler (sayı, yüzde ve ortalama) ile sunulmuştur. Verilerin dağılımının normallik gösterip göstermediği Kolmogrov Smirnov testi ile saptanmıştır. Bağımsız iki gruba ait değişkenlerin ölçek puanları ile karşılaştırmasında Student's t testi, ikiden fazla bağımsız grubu bulunan değişkenlerin ölçek puanları ile karşılaştırmasında Tek Yönlü Varyans Analizi (ANOVA), farkın hangi gruptan kaynaklandığını belirlemek amacıyla Tukey testi ve ölçekler arasındaki ilişkinin değerlendirilmesinde Pearson korelasyon analizi kullanılmıştır. Güvenilirlik analizi ile ölçeklerin Cronbach alfa değerleri hesaplanmıştır. Araştırmada $p<.05$ ise istatistiksel olarak anlamlılık kabul edilmiştir.

\section{Araştırmanın Etik Yönü}

Araştırmanın yürütülebilmesi için araştırmanın gerçekleştirildiği üniversitenin etik kurulundan 02.06.2020 tarihli ve 56786525-050.04.04/31090 say1l etik kurul onay1 ve ilgili kurumdan 87103392-302.12.01.-E.1556 numaral1 izin yaz1s1 alınmıştır. Helsinki Deklerasyonu Prensipleri’ne uygun olarak veri toplama aşaması gerçekleştirilmiş, öğrencilerden çevrimiçi bağlantı ile onamları alınmıştır. Araştırmada kullanılan ölçeklerle ilgili yazarlardan kullanım izni alınmıştır.

\section{Bulgular}

Araştırmaya katılan öğrencilerin yaş ortalamasının $20.94 \pm 1.51$ olduğu ve çoğunluğunun (\%81.5) kadınlardan oluştuğu belirlenmiştir. Öğrencilerin \%81.5'inin ekonomik durumunu orta düzey olarak algıladığı; \%36. 1'inin dördüncü sınıf, \%35.2'sinin duygusal kişilik yapısında ve \%80.6'sının çekirdek aile tipine sahip olduğu saptanmıştır. Öğrencilerin \%58.6'sının hemşirelik mesleğini sevdiği, \%78.9'unun empatiye yönelik ve \%61.7'sinin iletişime yönelik bir eğitim aldığı belirlenmiştir (Tablo 1).

Öğrencilerin EEÖ toplam puan ortalamasının 68.14 \pm 8.52 olduğu belirlenmiştir. Öğrencilerin BBS-A-Hemşire toplam puan ortalamasının $4.13 \pm 0.56$ olduğu ve alt boyutlar değerlendirildiğinde toplam puan ortalamalarının sırayla karar verme kontrolü (4.18 \pm 0.63$)$, klinik durum (4.17 \pm 0.59$)$, kişisel yaşam durumu (3.98 \pm 0.71$)$ olduğu belirlenmiştir (Tablo 2).

Tanıtıcı özellikleri ile toplam EEÖ puan ortalamaları karşılaştırıldığında; öğrencilerin, sınıfı (p =.969), cinsiyeti ( $\mathrm{p}=.969)$, aile tipi $(\mathrm{p}=.494)$ ve iletişim becerileri eğitimi $(\mathrm{p}=.087)$ ile toplam EEÖ puan ortalamaları arasında anlamlı fark bulunmadığı belirlenmiştir (Tablo 3).

Öğrencilerin algıladıkları ekonomik durumları ve toplam EEÖ puan ortalamalarında ise anlamlı bir fark bulunduğu ve algılanan ekonomik durumunu kötü olarak belirtenlerin, orta ya da iyi olanlarla karşılaştırıldığında puan ortalamalarının düşük ve aradaki farkın istatistiksel olarak önemli olduğu belirlenmiştir (p =.015), (Tablo 3).

Öğrencilerin kişilik yapısı ile toplam EEÖ puan ortalamaları arasında anlamlı bir fark bulunduğu ve dışa dönük, kişilik yapısında olanların içe dönük, mantıklı/kuralcı ve duygusal kişilik yapısında olanlara göre puan ortalamalarının yüksek ve aradaki farkın istatistiksel olarak önemli olduğu saptanmıştır ( $p=.001)$. Öğrencilerin mesleği sevme durumu ve toplam EEÖ puan ortalamaları karşılaştırıldığında mesleğini seven öğrencilerin, sevmeyen ve kararsız olanlara göre puan ortalamalarının yüksek olduğu ve gruplar arası farkın istatistiksel olarak anlamlı bulunduğu belirlenmiştir (p $=.001$ ), (Tablo 3).

Araştırmada empatiye yönelik bir eğitim alan öğrencilerin, almayan öğrencilere göre toplam EEÖ puan ortalamalarının yüksek olduğu saptanmıştır $(\mathrm{p}=.029)$, (Tablo 3). 
Tablo 1. Öğrencilerin Tanttıcı Özelliklerine Ilişskin Bulgular

\begin{tabular}{lcc}
\hline Tanıtıcı Özellikler & $\boldsymbol{n}$ & $\boldsymbol{\%}$ \\
\hline Sınıf & & \\
2. sınıf & 80 & 35.3 \\
3. sınıf & 65 & 28.6 \\
4. sınıf & 82 & 36.1 \\
Cinsiyet & & \\
Kadın & 185 & 81.5 \\
Erkek & 42 & 18.5 \\
Algılanan Ekonomik Durum & & \\
Kötü & 15 & 6.6 \\
Orta & 185 & 81.5 \\
İyi & 27 & 11.9 \\
Kişilik Yapısı & & \\
İçe dönük & 42 & 18.5 \\
Dışa dönük & 34 & 15.0 \\
Mantıklı/Kuralcı & 71 & 31.3 \\
Duygusal & 80 & 35.2 \\
Aile Tipi & & \\
Çekirdek aile & 183 & 80.6 \\
Geniş aile & 44 & 19.4 \\
Hemşirelik Mesleğini Sevme Durumu & & \\
Seviyorum & 133 & 58.6 \\
Sevmiyorum & 14 & 35.2 \\
Kararsızım & 80 & 38.3 \\
İletişim Becerilerinin Geliştirilmesine Yönelik Eğitim Alma Durumu * & \\
Evet & 87 & 78.9 \\
Hayır & 140 & \\
Empatik Becerilerinin Geliştirilmesine Yönelik Eğitim Alma Durumu * & \\
Evet & 48 & \\
Hayır & 179 & \\
\hline Senine, Kurs & \\
\hline
\end{tabular}

*Seminer, kurs vb

Tablo 2. Öğrencilerin Ölçek Puan Ortalamaları

\begin{tabular}{lcccc}
\hline Ölçek puan ortalamaları & Ort & SS & Min & Max \\
\hline EEÖ* & 68.14 & 8.52 & 39.00 & 88.00 \\
& & & & \\
BBS-A**-Hemşire Alt Boyutları & 4.17 & .59 & 1.43 & 5.00 \\
Klinik durum alt boyutu & 3.98 & .71 & 1.25 & 5.00 \\
Kişisel yaşam durumu alt boyutu & 4.18 & .63 & 1.33 & 5.00 \\
Karar verme kontrolü alt boyutu & 4.13 & .56 & 1.35 & 5.00 \\
BBS-A-Hemşire toplam puanı & &
\end{tabular}

*Empatik Eğilim Ölçeği, ** Bireyselleştirilmiş Bakım Skalası-Hemşire 
Tablo 3. Öğrencilerin Tanıtıcı Özelliklerine Göre Ölçek Puan Ortalamalarının Karşılaş̧tırılması

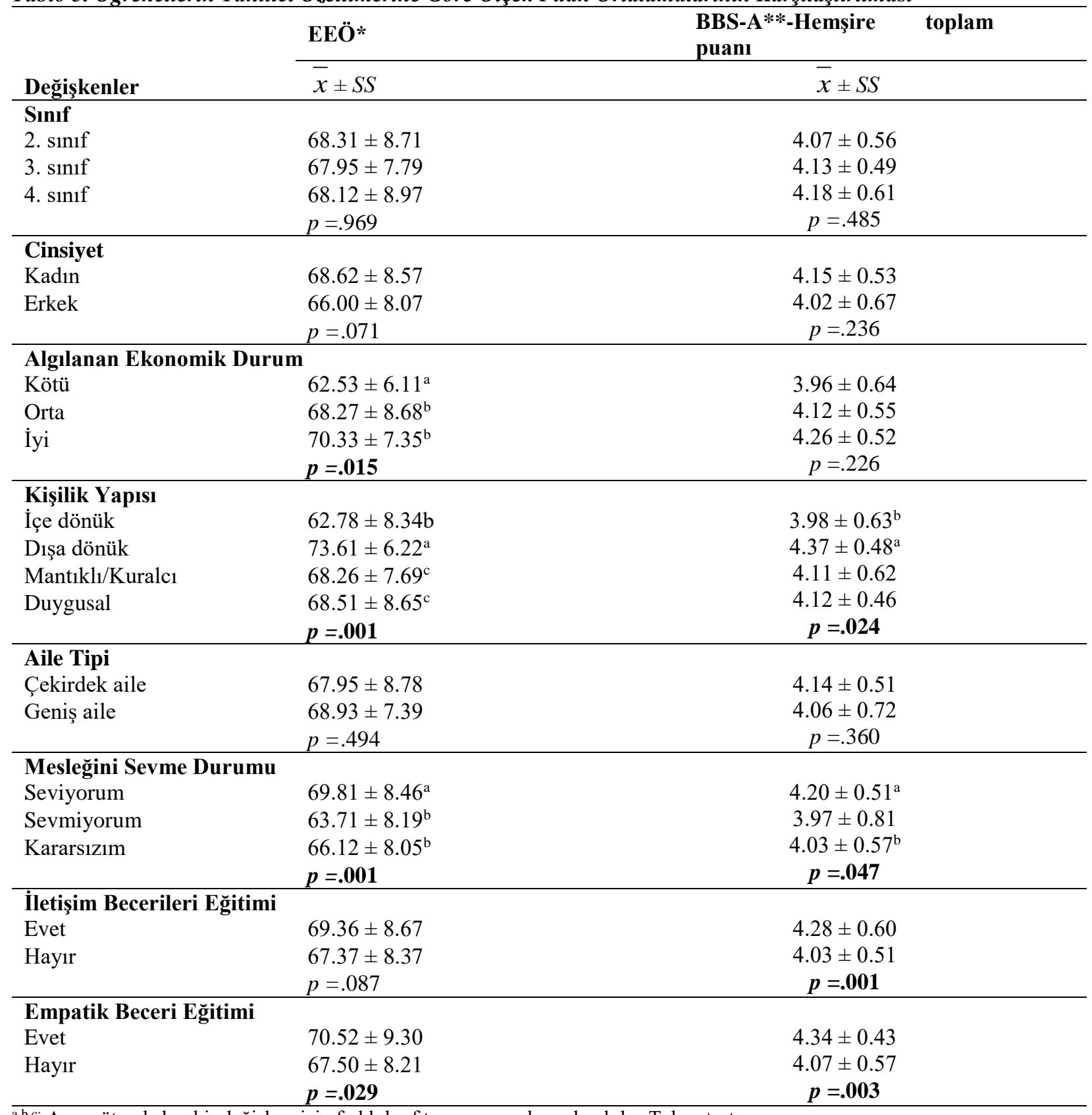

a,b,c: Aynı sütunda her bir değișken için farklı harf tanınan gruplar anlamlıdır, Tukey test.

*Empatik Eğilim Ölçeği, ** Bireyselleştirilmiş Bakım Skalası-Hemşire.

Tablo 4. Öğgrencilerin EEÖ ve BBS-A-Hemşire Ölçek Puanları Arasındaki Ilişki

\begin{tabular}{lll}
\hline \multirow{2}{*}{ BBS-A**-Hemşire Puanları } & EEÖ* & $\boldsymbol{p}$ \\
\cline { 2 - 3 } & $\boldsymbol{r}$ & $\mathbf{. 0 0 1}$ \\
Klinik durum alt boyutu & .413 & $\mathbf{. 0 0 1}$ \\
Kişisel yaşam durumu alt boyutu & .285 & $\mathbf{. 0 0 1}$ \\
Karar verme kontrolü alt boyutu & .329 & $\mathbf{. 0 0 1}$ \\
\hline
\end{tabular}

*Empatik Eğilim Ölçeği, ** Bireyselleştirilmiş Bakım Skalası-Hemşire

Öğrencilerin toplam EEÖ puan ortalamaları ile BBS-A-Hemşire ve alt boyutlarından aldıkları puan ortalamaları arasındaki ilişki değerlendirildiğinde, toplam EEÖ puan ortalamaları ile BBS-A-Hemşire toplam puan ortalamaları arasında pozitif yönlü zayıf ilişki olduğu saptanmıștır $(r=.396, p=.001)$. Öğrencilerin EEÖ puan ortalamaları ile BBS-A-Hemşire alt boyutlarından klinik durum alt boyutu arasında pozitif yönde orta düzeyde bir ilişki bulunurken $(\mathrm{r}=.413, \mathrm{p}=.001)$, öğrencilerin EEÖ puan ortalamaları ile kişisel yaşam durumu alt boyutu $(\mathrm{r}=.283, \mathrm{p}$ $=.001$ ) ve karar verme alt boyutu $(\mathrm{r}=.329, \mathrm{p}=.001$ ) arasında pozitif yönlü zayıf ilişki olduğu saptanmıştır (Tablo 4). 


\section{Tartışma}

Hemşirelerin empatik eğilimlerinin yüksek olmasının, hastalara verilen hemşirelik bakımının kalitesini de etkileyeceği bildirilmektedir (5). Araştırmada hemşirelik öğrencilerin empatik eğilimlerinin orta düzeyde; bireyselleştirilmiş bakım algılarının iyi düzeyde olduğu; öğrencilerin empatik eğilimleri arttıkça bireyselleştirilmiş bakım algılarının da arttığı belirlenmiştir.

Hemşireler bakım hizmeti sundukları sağlıklı/hasta bireyler ile iletişim kurmada ve mesleğin temel işlevi olan bakım eylemini gerçekleştirmede empatiyi kullanmaktadır $(2,22)$. Araştırmada öğrencilerin empatik eğilim düzeyinin orta düzeyde olduğu saptanmıştır. Literatürde araştırma bulgularına benzer sonuçlar bildirilmiş, hem öğrenci hemşirelerin $(5,6)$ hem de hemşirelerin $(8,16)$ empatik eğilim düzeylerinin orta düzeyde olduğu vurgulanmıştır. Gazo ve ark. (2021), öğrenci hemşireler ve öğretmen adaylarının empatik düzeylerini karşılaştırdıkları çalışmada empatik eğilim düzeylerinin orta düzeyde olduğu ve aralarında istatistiksel olarak anlamlı bir fark olmadığı yalnızca cinsiyete göre empatik eğilim düzeyleri arasında farklılıklar olduğu belirlenmiştir (23). Montanari ve ark. (2015) ile Caranza'nın (2015) öğrenci hemşirelerle yaptığı iki farklı çalışmada öğrenci hemşirelerin empatik eğilim düzeylerinin yüksek olduğu saptanmıştır $(24,25)$. Bireylerde empatik eğilimin değiştirilmesi ve geliştirilmesinin güç olduğu ve bunun için uzun süreli bir eğitime ihtiyaç duyulduğu belirtilmektedir (26). Araştırma bulgularında öğrencilerin empatik eğilim düzeyinin orta düzeyde olması eğitim aldıkları müfredatta empatik eğilim düzeylerinin geliştirilmesine yönelik bir eğitimin olmaması ve çoğunluğunun (\%78.9) müfredat dışında empatik becerilerin geliştirilmesine yönelik bir eğitim almadığını belirtmesi ile ilişkilendirilebilir. Bu sonuç hemşirelik müfredatında empatik eğilim ve becerilerin geliştirilmesine yönelik eğitimlere birinci sınıftan son sınıfa kadar uzun süreli biçimde yer verilmesine gereksinim olduğunu düşündürmektedir.

Araştırmada hemşirelik öğrencilerinin ekonomik durumu, kişilik yapısı, mesleği sevme durumu ve empatik becerilerin geliştirilmesine yönelik eğitim alma durumları ile empatik eğilim düzeyleri arasında ilişki olduğu saptanmıştır. Araştırmada ekonomik durumu iyi olan öğrencilerin empatik eğilim düzeylerinin daha yüksek olduğu belirlenmiştir. Literatürde öğrencilerle yapılan çalışmalarda gelir durumu gider durumuna göre daha iyi olanların empatik eğilim düzeylerinin daha yüksek olduğu belirtilmektedir $(27,28)$. Çalışma bulgularımız literatürle benzerlik göstermekle beraber, öğrencilerin ekonomik durumunun iyi olması, daha az maddi kaygı yaşamalarına ve kendilerine olan güvenlerinin artarak daha kolay iletişim kurmaları ile ilişkili olduğunu düşündürmektedir.

Kişilik yapısı dışa dönük olan öğrencilerin empatik eğilim düzeylerinin daha yüksek olduğu belirlenmiştir. Literatürde farklı öğrenci grupları ile yapılan çalışmalarda da dişadönük kişilik yapısı ile empatik eğilim arasında istatistiksel açıdan önemli bir ilişki olduğu saptanmıştır $(29,30)$. Araştırmalardan elde edilen sonuçlar, dişa dönük kişilerin empatik eğilimlerinin daha iyi oldugunu göstermektedir. Dişa dönük kişilerin iletişim becelerini daha sık kullanmalarının empatik eğilimleri üzerinde olumlu etki yarattığı düşünülmektedir.

Araştırmada mesleğini sevdiğini belirten öğrencilerin empatik eğilim düzeylerinin daha yüksek olduğu belirlenmiştir. Araştırma bulgularına benzer şekilde Özpulat ve Bilgen Sivri’nin (2014) çalışmasında da mesleğini seven hemşirelik öğrencilerinin empatik eğilimlerinin yüksek olduğu saptanmıştır (30). Çınarlı ve ark. (2016) hemşirelerin tükenmişlik ve empatik eğilim düzeylerini araştırdıkları çalışmasında, mesleği sevenlerin empatik eğilim düzeylerinin daha yüksek olduğu belirlenmiştir (31). Bu bağlamda mesleğini sevmeyenlerin, sevenlere göre empatik eğilim düzeylerinin daha düşük olacağı düşünülmektedir.

Araştırmada empatik beceri eğitimi alan öğrencilerin empatik eğilim düzeylerinin yüksek olduğu bulunmuştur. Araştırma bulgularının aksine, Üstündağ ve ark.'nın (2018) çalışmasında hemşirelik öğrencilerinin empatik beceri eğitimi alma durumları ile empatik eğilim düzeyleri arasında fark saptanmamıştır (32). Gazo ve ark.'nın (2021) öğrenci hemşirelerle ve öğretmen adayları ile yaptığı çalışmada, öğrencilerin empatik eğilimlerinin eğitim yılı arttıkça yükseldiği belirlenmiştir (23). Literatürde empatik eğilimin eğitimle arttırılamayacağını belirten çalışmalar olmakla birlikte $(26,32)$, eğitim müfredatı içerisine yerleştirilen psikodrama gibi tekniklerle öğrencilerin empatik eğilim düzeylerinin arttırabileceğini belirten çalışmalar da yer almaktadır $(23,33)$. Empatinin duygusal boyutunu oluşturan empatik eğilimin bir kişilik özelliği olması nedeniyle, geliştirilebilmesi için yalnızca bilişsel ve beceri yönünden değil, kişilik ve tutum yönünden de desteklenmesi gerekmektedir. Bu nedenle empatik eğilim düzeylerinin arttırılabilmesi için uzun süreli eğitimlere ihtiyaç duyulmaktadır.

Bireyselleştirilmiş hemşirelik bakımı, bakımda istendik sonuçlar elde edebilmek için hasta bireylere özgü tasarlanmış hemşirelik faaliyetleri olarak tanımlanmıştır (15). Bu nedenle sağlık bakım hizmetlerinin kalitesinin değerlendirilmesinde, sağlıklı/hasta bireylere bireyselleştirilmiş bakım sağlanabilmesi oldukça önemlidir (3). Araştırmada hemşirelik öğrencilerinin bireyselleştirilmiş bakım algılarının yüksek düzeyde olduğu belirlenmiştir. Literatürde yer alan diğer çalışma sonuçları ile karşılaştırıldığında öğrencilerin ölçekten aldıkları toplam puan ortalamaları benzerdir $(1,7)$. Ayrıca hemşireler ile yapılan çalışmalarda da bireyselleştirilmiş bakım algıları yüksektir $(14,15,33)$. Araştırmada, öğrencilerin en yüksek alt boyut puan ortalamasının karar verme durumu alt boyutundadır. Klinik durum ve kişisel yaşam durumu alt boyutu puan ortalamaları birbirine yakın ve daha düşüktür. Öğrencilerin ölçek alt boyutlarından aldığ 1 puan ortalamaları hemşirelik öğrencileri ve hemşireler $(5,35)$ ile gerçekleştirilen diğer çalışma sonuçları ile benzerlik göstermektedir. Karar verme alt boyutunun ortalamasının yüksek olması, hem öğrencilerin hem de hemşirelerin hasta bireyleri kendi bakımlarında söz sahibi olma ve kendi bakımıyla ilgili kararlara katılma gibi konularda desteklediğini düşündürtmektedir.

Araştırmada öğrencilerin kişilik yapısı, mesleği sevme durumu, iletişim ve empati becerilerine yönelik eğitim alma durumları ile bireyselleştirilmiş bakım algısı düzeyleri arasında ilişki olduğu saptanmıştır. Dışa dönük kişilik yapısına sahip olan, mesleğini seven, iletişim ve empati becerilerine yönelik eğitim alan öğrencilerin bireyselleştirimiş 
bakım algıları daha yüksektir. Literatürde hemşirelik öğrencilerinin bireyselleştirilmiş bakım algılarını inceleyen sınırlı sayıda çalışma bulunmakta; bu çalışmalarda da öğrencilerin bireyselleştirmiş bakım algıları ile ilişkili bulunan değişkenlerin incelenmediği görülmektedir $(1,35)$. Kişilik yapısı, mesleği sevme durumu, iletişim ve empati konusunda verilen eğitimler öğrencilerin bireyselleştirilmiş bakım algısını etkileyebilir.

Hemşirelerin hastalara bakım verirken her bir bireyin ayrı özelliklere sahip olduğu ve bu özellikleri doğrultusunda ihtiyaçlarının değişkenlik gösterdiğine ilişkin farkındalıklarının olması ve bakım ile ilgili karar verme konusunda işbirliği halinde olmaları, empati yapabilme becerisinin bir göstergesi olan yüksek empatik eğilim varlığında mümkündür $(5,17)$. Araştırma bulguları EEÖ ile BBS-A-Hemşire ve alt boyutları arasında pozitif yönde bir ilişki olduğunu göstermektedir. Literatürde hemşirelik öğrencilerinin empatik eğilim düzeyleri ve bireyselleştirilmiş bakım algıları arasındaki ilişkiyi arayan bir çalışmaya rastlanmamakla birlikte hemşirelerle ile gerçekleştirilen bir araştırmada da benzer sonuçlar bildirilmiştir (5). Hemşirelik öğrencilerinin empatik eğilimlerinin yüksek olması bakım verdikleri sağlıklı/ hasta bireyin duygu ve düşüncelerini anlamaları ve bakımı sağlıklı/hasta bireye özgü planlayabilmeleri açısından önemlidir.

\section{Kisıtlılıklar}

$\mathrm{Bu}$ araştırmanın bazı sınırlılıkları bulunmaktadır. Araştırmanın sınırlılıklarından biri yalnızca bir üniversitenin hemşirelik bölümünde öğrenim gören ve araştırmaya katılmaya gönüllü olan öğrenciler ile yapılmış olmasıdır. Bu nedenle araştırma verileri genellenemez. Bir diğer sınırlılık ise empatik eğilim düzeylerinin öğrencilerin öznel algılarının değerlendirmesi ile belirlenmiş olmasıdır. Ayrıca araştırma verilerinin kesitsel olarak toplanması, araştırma değişkenleri arasında nedensel ilişkinin kurulmasını engellemektedir. Konu ile ilgili yapılacak çalışmalarda verilerin boylamsal olarak toplanması, empatik eğilim ve bireyselleştirilmiş bakım algıları arasındaki nedensel ilişkileri ortaya koyabilir.

\section{Sonuçların Uygulamada Kullanımı}

Araştırmanın sonuçları, öğrencilerin empatik eğilim düzeylerinin orta, bireyselleştirilmiş bakım algılarının iyi düzeyde olduğunu göstermekte ve empatik eğilim düzeyleri ile bireyselleştirilmiş bakım algıları ile alt boyutları arasında pozitif yönde bir ilişki olduğunu belirtmektedir. Ayrıca, hemşirelik öğrencilerinin bazı tanıtıcı özellikleri ile empatik eğilim düzeyleri (ekonomik durumu, kişilik yapısı, mesleği sevme durumu ve empatik becerilerin geliştirilmesine yönelik eğitim alma durumları) ve bireyselleştirilmiş bakım algıları (kişilik yapısı, mesleği sevme durumu iletişim becerilerinin ve empatik becerilerin geliştirilmesine yönelik eğitim alma durumları) üzerinde etkisi olduğu saptanmıştır. Bu sonuçlardan yola çıkarak, hemşirelik öğrencilerinin mesleki eğitimleri süresince empatik eğilimlerini arttıracak eğitim uygulamaları (psiko drama vs.) ile bireyselleştirilmiş bakım algılarının da arttırılacağı düşünülmektedir. Öğrenci hemşirelerin empatik eğilimlerini ve bireyselleştirilmiş bakım algılarını inceleyen daha geniş örneklemli ve farklı değişkenleri (kişilik, mizaç vb.) içeren çalışmaların yapılması önerilir.

\section{Bilgilendirme}

Araştırmacılar arasında herhangi bir çıkar çatışması bulunmamaktadır. Araştırmacıların katkı oranı beyanı şu şekildedir: Fikir/kavram AEK; tasarım AEK, YÇ, FUŞ; denetleme/danışmanlık AEK, FUŞ; veri toplama ve işleme AEK, YÇ; analiz ve yorum AEK, YÇ, FUŞ; kaynak taraması: AEK, YÇ, FUŞ; makalenin yazımı: AEK, YÇ, FUŞ; eleştirel düşünme: AEK, FUŞ; araştırmanın bütçesi: AEK, YÇ, FUŞ. Araştırmanın gerçekleştirildiği üniversitenin etik kurulundan (say1: 56786525-050.04.04/31090) ve öğrencilerin öğrenim gördüğü fakülteden (say1: 87103392302.12.01.-E.1556) yazılı izin alınmıştır. Ayrıca araştırmada yer alan öğrencilerden de çevrimiçi bağlantı ile onamları alınmıştır. Bu araştırma herhangi bir kurum ya da kuruluştan finansal destek almamıştır. 


\section{Kaynaklar}

1. Doğan P, Tarhan M, Kürklü A. Hemşirelik öğrencilerinin bireyselleştirilmiş bakım algıları ile ahlaki duyarlılık düzeyleri arasındaki ilişki. HEAD 2019; 16(2), 119-124.

2. Stein-Parbury J. Patient and Person, In Stein-Parbury J. Interpersonal skills in nursing. 6th Ed. Australia: Elsevier Health Sciences; 2018: 110-125.

3. Toru F. Hemşirelik uygulamalarının kilit noktası: bireyselleştirilmiş bakım. Adnan Menderes Üniversitesi Sağlık Bilimleri Fakültesi Dergisi 2020; 4(1), 46-59.

4. Gosselin E, Bourgault P, Lavoie S. Association between job strain, mental health and empathy among intensive care nurses. Nurs Crit Care 2016; 21, 137-45.

5. Güven-Özdemir N, Sendir M. The relationship between nurses' empathic tendencies, empathic skills, and individualized care perceptions. Perspect Psychiatr Care 2020; 56(3), 732-737.

6. Pazar B, Demiralp M, Erer İ. The communication skills and the empathic tendency levels of nursing students: a cross-sectional study. Contemp Nurse 2017; 53(3), 368-377.

7. Haley B, Heo S, Wright P, Barone C, Rettigantid MR, Anders M. Effects of using advancing care excellence for seniors simulation scenario on nursing student empathy; a randomized controlled trial. Clin Simul Nurs 2017; 13(10), 511-519.

8. Özcan, H. Hemşirelerin empatik eğilim ve empatik becerileri: Gümüşhane Örneği. Gümüşhane Üniversitesi Sağlık Bilimleri Dergisi 2012; 1(2), 60-68.

9. Mula JM, Estrada JG. Impact of nurse-patient relationship on quality of care and patient autonomy in decisionmaking. Int J Environ Res Public Health 2020; 17 (3), 835.

10. Suhonen R, Valimaki M, Leino-Kilpi H. Individualized care, quality of life and satisfaction with nursing care. J Adv Nurs 2005; 50, 282-92.

11. Suhonen R. Understanding the basics and importance of individualized nursing care. In Suhonen R, Stolt M, Papastavrou E. Individualized care theory, measurement, research and practice. 1th Ed.Switzerland; Springer International Publishing; 2019: 17-25.

12. Rodríguez-Martin B, Martin-Martin R, Suhonen R. Individualized care scale-patient: a Spanish validation study. Nurs Ethics. 2019; 26(6), 1791-1804.

13. Papastavrou E, Acaroglu, R, Sendir M, Berg A, Efstathiou G et al. The relationship between individualized care and the practice environment: an international study. Int J Nurs Stud 2015; 52(1), 121-133.

14. Karayurt Ö, Ursavaş FE, İşeri Ö. Hemşirelerin bireyselleştirilmiş bakım verme durumlarının ve görüşlerinin incelenmesi. AUHSJ 2018; 9(2), 163-169.

15. Can S, Acaroğlu R. Relation of professional values of the nurses with their individualized care perceptions? FNJN 2015; 23(1), 32-40.

16. Tunç P, Gitmez A, Krespi-Boothby M.Yoğun bakım ve yataklı servis hemşirelerinde duygusal emek stratejilerinin empatik eğilim açısından incelenmesi. Anadolu Psikiyatri Derg 2014; 15, 45-54.

17. Suhonen R, Leino-Kilpi H, Valimaki M. Development and psyhometric properties of the individualized care scale. J Eval Clin Pract 2005; 11(1), 7-10.

18. Acaroglu R, Suhonen R, Sendir M, Kaya H. Reliability and validity of Turkish version of the individualised care scale. J Clin Nurs 2011; 20(1-2), 136-145.

19. Acaroğlu R, Şendir M. Bireyselleştirilmiş bakımı değerlendirme skalaları. FNJN 2012; 20(1), 10-16.

20. Suhonen R, Schmidt LA, Radwin L. Measuring individualized nursing care: Assessment of reliability and validity of three scales. J Adv Nurs 2007; 59(1), 77-85.

21. Dökmen Ü. Empatinin yeni bir modele dayanılarak ölçülmesi ve psikodrama ile ölçülmesi. Ankara Üniversitesi Eğitim Bilimleri Dergisi 1988; 21, 155-190.

22. Özkan HA, Akten IM, Yaşar S. Hemșirelikte bakım kavramı, İçinde Özkan, S. Hemşirelikte Bilim, Felsefe ve Bakımın Temelleri. 1. Basım. İstanbul: Akademi Basın ve Yayın; 2014: 97-110.

23. Gazo AM, Mhaidat FA, Alharbi BH. Empathic Tendencies among Student Nurses and Student Teachers: A Comparative Study. JESR 2021; 11(3), 202.

24. Montanari P, Petrucci C, Russo S, Murray I, Dimonte V, Lancia L. Psychometric properties of the Jefferson Scale of Empathy Health Professional Student's version: An Italian validation study with nursing students. Nursing \& Health Sciences 2015; 17(4), 483-491.

25. Carranza AN. Clinical Simulation Experiences in Nursing Schools: Senior Student Nurses' Empathetic Communication Ability. [Honors Thesis], Texas; 2015.

26. Mete S, Gerçek E. PDÖ Yöntemiyle Eğitim Gören Hemşirelik Öğrencilerinin Empatik Eğilim Ve Becerilerinin İncelenmesi. Cumhuriyet Üniversitesi Hemşirelik Yüksek Okulu Dergisi 2005; 9:11-17.

27. Yurttaş A, Aras GN. Hemşirelik öğrencilerinin kültürlerarası duyarlılıkları ile empati düzeyleri arasındaki ilişki, Genel Sağlık Bilimleri Dergisi 2020; 2(3), 117-125.

28. Pala A. Öğretmen Adaylarının Empati Kurma Düzeyleri Üzerine Bir Araştırma. Pamukkale Üniversitesi Eğitim Fakültesi Dergisi 2008; 1(23), 13-23.

29. Kapıkıran N. Üniversite Ögrencilerinde Ahlaki Davranışın Empatik Eğilim ve Kendini Ayarlama Açısından İncelenmesi. Türk Psikolojik Danışma ve Rehberlik Dergisi 2007; 3 (28), 33-47.

30. Özpulat F, Bilgen-Sivri B. Hemşirelik öğrencilerinin empatik eğilimleri ve eleştirel düşünme becerileri. SSTB 2014; 11(4), 31-49. 
31. Çınarlı T, Koç Z, Duran L. Burnout and Emphatic Tendency levels in Emergency Nurses. EAJEM 2016; 15, 1816.

32. Üstündă̆ H, Bayar N, Y1lmaz E, Türel G. Hemşirelik öğrencilerinin empatik eğilim düzeyleri ve problem çözme becerileri. Sağlık Bilimleri ve Meslekleri Dergisi 2018; 5(2), 227-235.

33. Ergün S, Duran S, Işık R, Kızıl Sürücüler H, Çalışkan T. Empathic tendencies and empathic skill levels of nursing students: A descriptive and cross-sectional study. Kocaeli Üniversitesi Sağlık Bilimleri Dergisi 2019; 5(3), 150155.

34. Zengin-Aydin L, Büyükbayram Z. Hemşirelerin mesleki tutumlarına göre bireyselleştirilmiş bakım algıları. Türkiye Klinikleri J Nur Sci 2020; 12(2), 198-206.

35. Güner GS, Ovayolu Ö, Ovayolu N. Hemşirelik öğrencilerinin bireyselleştirilmiş bakıma ilişkin durumlarının incelenmesi. DEUHFED [online] https://dergipark.org.tr/tr/pub/deuhfed/issue/53759/562939. 